乳幼児顎顔面模型とその立体的観察方法

口唇・口蓋裂患者の顎顔面発育研究

和田健・辻忠良・宮崎正

\title{
A maxillo-facial model and its tri-dimensional observation method in infant
}

\section{On the study of maxillo-facial developmental growth in the cleft lip and palate patients}

Takeshi Wada, Tadayoshi TsujI, Tadashi Mryazaki

諸

論

口唇・口蓋裂患者の顎顔面の形態異常に関する顎発育 研究は Cooper ${ }^{1)}$ 以来多くの業績をみるとともにこれら 患者の治療の改善に大きく貢献して来た．正常人の上顎 と口唇口蓋裂患者の上顎との間には, 形態, 大きさ, 位 置的関係において基本的に相異があることは Coupe, Subtelny'2),Peyton ${ }^{3), 4)}$ らによりすでに指摘されたとお りであり, それにもとずいて諸種の治療が考案, 改善さ れつつあるが, なお現在においても Flat nose, Cross bite, Flat Lip, 鼻孔の非対称などがしばしば見られ， いまだに満足な結果を得ることは困難である.

今日, これら口唇・口蓋裂患者の治療において特に Maxillar displacement の好置が問題とされ Pruzan$\mathrm{sky}^{5)}$, Subtelny6) らは早期矯正治療の必要性を報告し, さらに $\mathrm{McNeil}{ }^{7)}$ は䋶矯正装置の応用による上顎歯槽弓

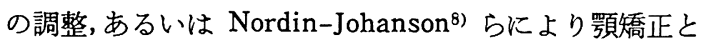
骨移植の併用が試みられ，本邦において藤野 ${ }^{9)}$, 平川10)

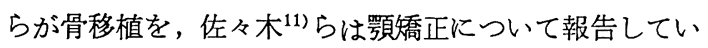
る.しかしこれらの治療が乳児期におこなわれ, その効 果は現在いまた明らかでなく, 顎発育途上にいかなる変 位をとるか, 顎矯正的治療の時期的問題, 骨移植の経過 あるいは主目的が達成されているか等に疑問が残る。し たがって, 研究の目を一段基本的な所に移し, 基礎とな る顎発育についての系統的研究, 特に乳幼児期における 顎発育様相の正確な観察と記録を行ない顎顔面の発育成

大阪大学歯学部口沿外科学第一講座 (主任 宮崎 正教授)

Dept. of Oral-Maxillo-Facial Surgery, Osaka Univ.

Dental School

(Chief : Prof. Tadashi Miyazaki)

受付 昭和 45 年 12 月 14 日
長を明らかにすることは，その治療上よりしてむ必要で あり,かつ重要である。

従来, この種の研究において, Pruzansky12), Hage$\mathrm{rty}^{13)}$ らは頭部 $\mathrm{X}$ 線規格写真および石高模型上における 直接的計測あるいは比较検討を行なっているが，これら は平面的な位置関係を論じたものであり破裂により分離 した各 Alveolar Segments の変位およびその発育状態 を三次元的に分析するには困難なところがあった。さら に上顎印象模型上における模型計测については破裂が顎 顔面に及ほすす影響を考虑するとともにその計測基盤は頭 蓋に求める必要があり,この両者の関係を具体的に表現 した報告は少い14). 特に乳幼児期におけるこの種の観察 記録について前記両者の関係を三次元的にとらえた報告 はない.

そこで著者らは乳幼児の顎顔面頭蓋の関係を具体的に 表現した製作の簡単な蕦顔面模型およびその計測方法を 考案したので報告する。

\section{模型採取装置}

模型採取装置は図 1-1 に示すように（A）顔面部印象 トレイ，(B) 上頸部印象トレイ，(C) 顔弓部の三部分 で構成される，顔面部トレイと上顎部トレイは（D）蝶 番によって接合され可動式とし，両者の間は（E）固定 ネジにより過屈曲のないよら固定されるようにした。顔 弓部は顔面部トレイに固定され，その両側に（F) 耳珠 点指示桿が装置してある.これによって耳珠点を含む上 顔面の計測点を包含し, 口腔内上買部を一括した模型と し顎顔面の形態を把握するように設計した。

\section{模型採取方法および模型製作法}

被検者を全身麻酔下，あるいは鎮静剤投与下にてベッ 


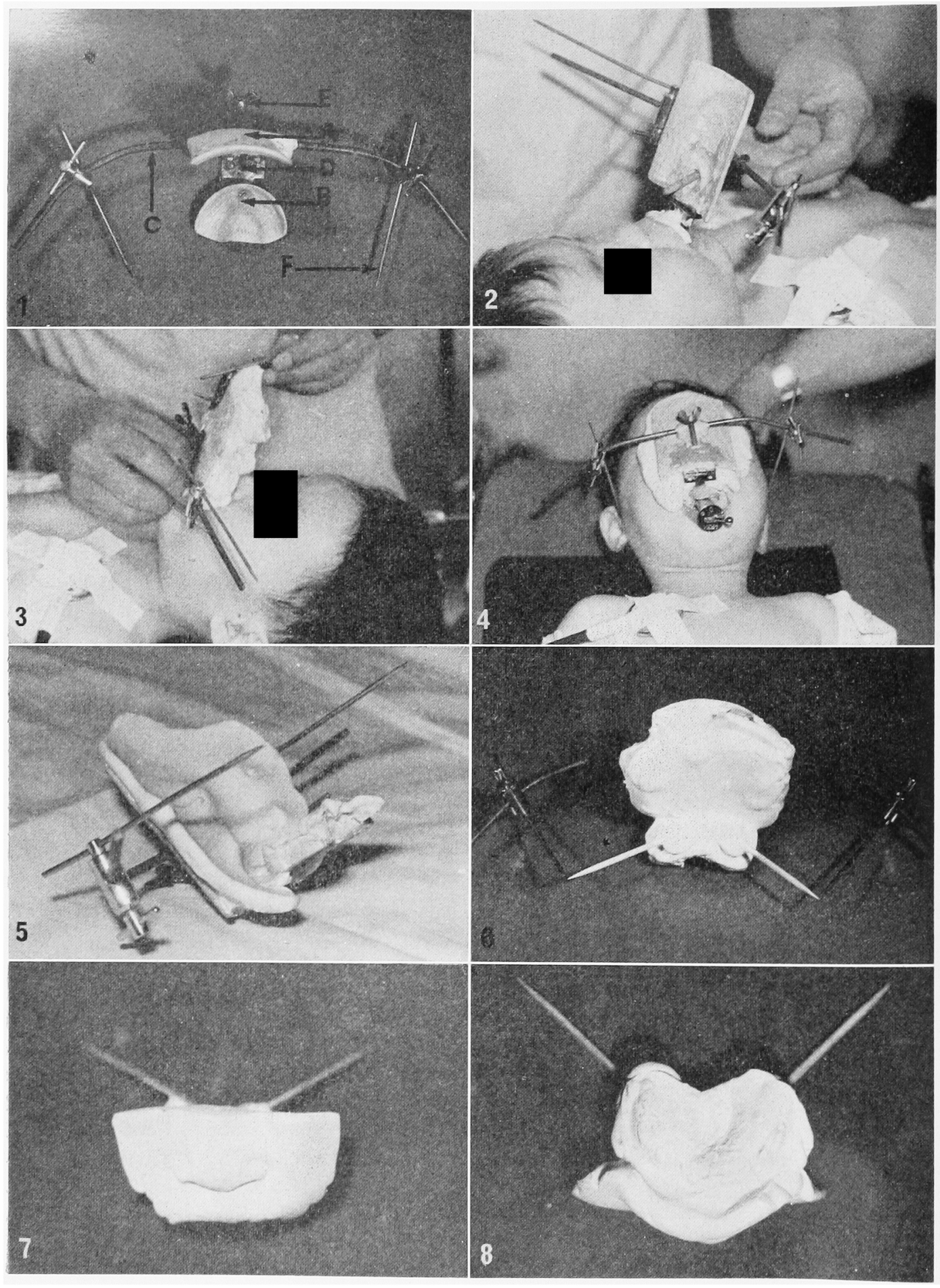



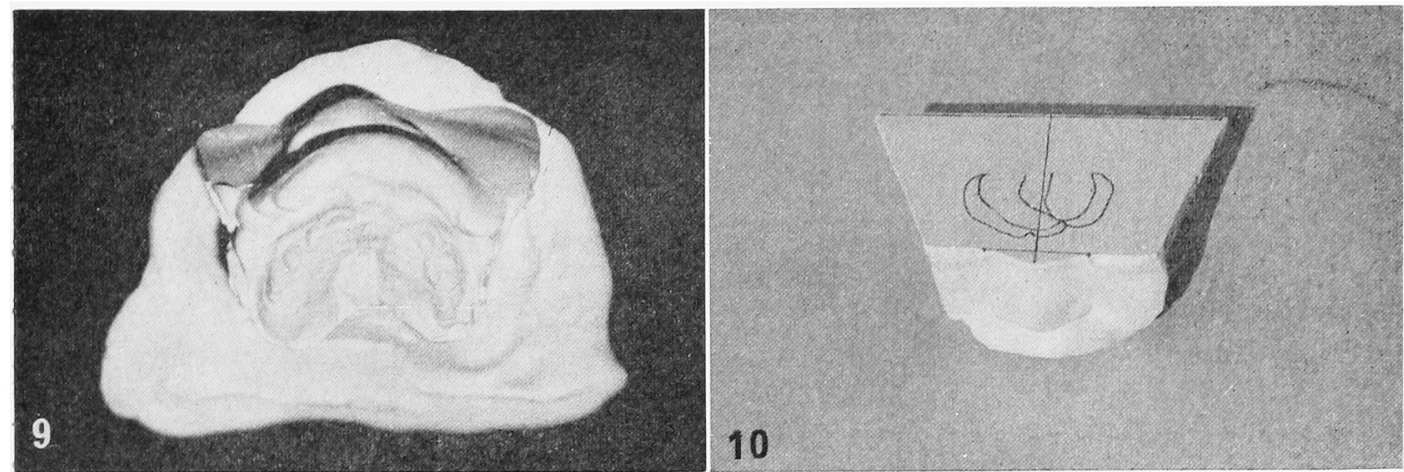

11

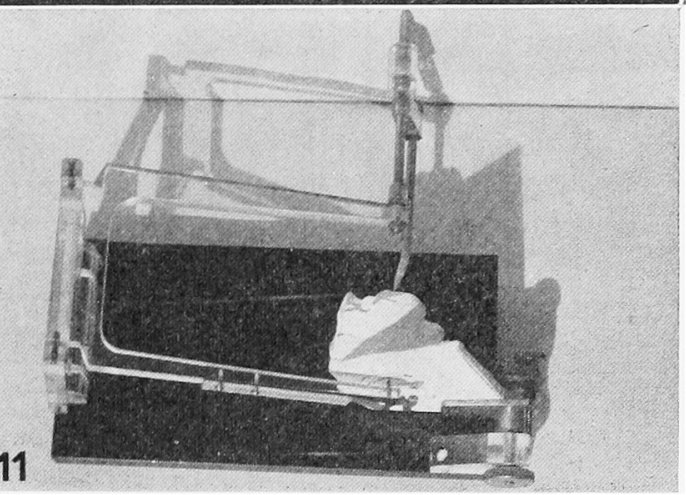

图 1 印象採得, 模型㹈作法

\section{下上に仰卧させる。}

まずアルギン酸印象材を練和し上類部トレイに盛り， 口腔内に插入して上顎印象を行なら。この時顔面部卜 レイは伸展されて乗入に際し 邪魔にならないよらにす る.

(図 1-2)

ついで，上買部トレイは術者の手指にて固定し口膑外 飞圧出された印象材を除去したのち練和したフルギン酸 印象材を顔面部トレイに盛り，内眼角点 (Entkanthion), 鼻部, 上口唇部が充分印象出来る様軽く王接し接合部六 ジにて固定する.（図 1-3）

次に，顔弓に装着してある耳珠点指示桿を両側耳珠点 (Tragion) に指示，固定する。（図 1-4）

印象材の硬化により顎顔面部トレイを被検者よりとり はずし印象採得を終る。これにより上顔面，鼻部，上口 唇部の印象扣よび耳珠点の指示がなされる。（図 1-5）

印象面石高注入に際し，上顎部印象面に練和した石旁 を注入乙順次顔面部印象面の両側内眼角点印記部迄盛上

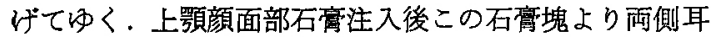
珠点指示桿に一致させた硬線を固定する・（図 1-6）

石高硬化後各トレイより模型をとりはずす，石育模型 上には両側耳珠点を指示する二本の硬線が残る。この模 型上に叔いて，両側内眼角点を結ぶ線より顔面上方部を 削合除去する。（図 1-7）
ガラス平板上によく練和した硬石高を薄く盛り両側耳 珠点指示硬線尖端部之両側内眼角点の中点の三点によっ て楧成される平面を作成する。（図 1-8, 9,10）

この平面に上顎各計測点，上顎雨槽頂線を投影描記す る. (図 1-11)

\section{模型計 測方法}

上顎各計測点，上罘歯槽形態を㖽顔面より観察するた めに必要な深さ, 幅, 高さの各基準面を模型上に設定す る.

すなわち両側内眼角点の中点および両側耳珠点の三点

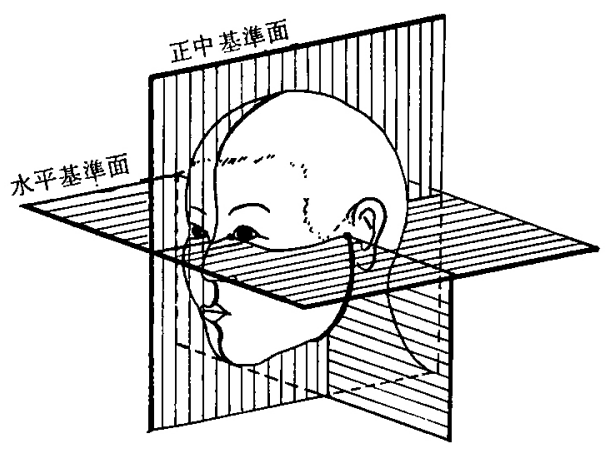

図 2 顎顔面測定の規準 


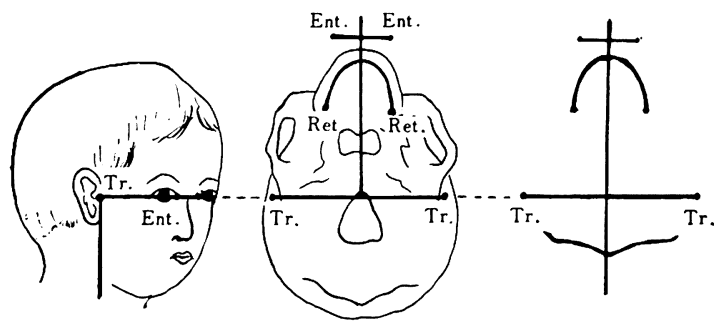

図 3 計 测 方 法

により構成される平面を水平基準面とし，この平面上に おいて両側耳珠点を結ぶ線を耳珠基線とする.この耳珠 基線の中点と両側内眼角点の中点を結ぶ線を正中線とす る. 水平基準面に上靧各計測点および上顎歯槽頂線をそ れぞれ投影し耳珠基線よりの深さ，正中線よりの幅を計 測する. 各計測点の水平基準面からの距離を高さとし, 歯槽頂線はその高さの推移を正中線より左右に実测展開 投影する。

\section{模型計測誤差}

この罘顔面模型の模型計測䛊差を調べるために同一症 例の模型の製作を 3 回試行し各々につき計測を行なった 結果は表1のとおりであった. 計测点間の計測には $1 / 10$

蕙 1 模型計測誤差

\begin{tabular}{|c|c|c|c|c|}
\hline 測定項目 & $\begin{array}{c}耳 \text { 珠 } \\
(\mathrm{L})-(\mathrm{R})\end{array}$ & \begin{tabular}{|c|} 
内 眼 角点 \\
$(\mathrm{L})-(\mathrm{R})$
\end{tabular} & $\begin{array}{c}\text { 耳珠点 }(\mathrm{R})- \\
\text { 内眼角点(R) }\end{array}$ & $\begin{array}{c}\text { 耳珠点(L)- } \\
\text { 内眼角点(L) }\end{array}$ \\
\hline 平均 值 & 120.6 & 30.6 & 74.5 & 76.1 \\
\hline 標準誤差 & 0.39 & 0.33 & 0.49 & 0.19 \\
\hline
\end{tabular}

深さの湘定

\begin{tabular}{|c|c|c|c|c|}
\hline 測定項目 & $\begin{array}{l}\text { 耳珠点(L)- } \\
\text { 中切蒾菌槽点 }\end{array}$ & $\begin{array}{l}\text { 耳珠点 }(\mathrm{R})- \\
\text { 中切菌菌槽点 }\end{array}$ & \begin{tabular}{|c|} 
珠点 $(\mathrm{L})-$ \\
後兒菊点(L) \\
\end{tabular} & $\begin{array}{c}\text { 珠点 }(\mathrm{R})- \\
\text { 後白菌点(R) } \\
\end{array}$ \\
\hline 平均 值 & 81.6 & 84.4 & 57.3 & 53.4 \\
\hline 標準誤差 & 0.41 & 1.28 & 0.18 & 1.46 \\
\hline
\end{tabular}

\section{歯槽面測定}

\begin{tabular}{|c|c|c|c|}
\hline 测定項目 & 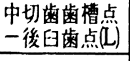 & 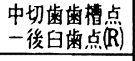 & 後臼葜点 $(\mathrm{L})-(\mathrm{R})$ \\
\hline 平均 值 & 29.5 & 35.4 & 38.9 \\
\hline 標华誤差 & 0.54 & 0.54 & 0.28 \\
\hline
\end{tabular}

高さの测定

\begin{tabular}{|c|c|c|c|}
\hline 測定項目 & 後白歯点(L) & 後臼菌点(R) & 中切蔽莑槽点 \\
\hline 平均 值 & 30.2 & 30.7 & 35.6 \\
\hline 標準誤差 & 0.85 & 0.55 & 0.69 \\
\hline
\end{tabular}

単位 $\mathrm{mm}$.

\begin{tabular}{|c|c|c|c|c|}
\hline 測定項目 & 䎷点 $(\mathrm{L})-(\mathrm{R})$ & 内眼角点 $(\mathrm{L})-(\mathrm{R})$ & \begin{tabular}{|c|} 
耳珠点(R)- \\
内眼角点(R)
\end{tabular} & $\begin{array}{c}\text { 耳珠点(L)- } \\
\text { 内眼角点(L) }\end{array}$ \\
\hline 平均 值 & 121.7 & 31.3 & 75.5 & 75.8 \\
\hline 標準誤差 & 0.73 & 0.27 & 0.28 & 0.16 \\
\hline $\begin{array}{l}\text { 模型計测值と } \\
\text { の比䩙検定 }\end{array}$ & $(-)$ & $(-)$ & $(-)$ & $(-)$ \\
\hline
\end{tabular}

哀 2 同一症例における生体直接計測値

\begin{tabular}{|c|c|c|}
\hline 測定項目 & 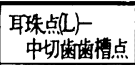 & $\begin{array}{c}\text { 耳珠点 }(\mathrm{R})- \\
\text { 中切歯藏㡟点 }\end{array}$ \\
\hline 平均值 & 82.0 & 84.4 \\
\hline 標準誤差 & 0.23 & 0.48 \\
\hline $\begin{array}{l}\text { 模型計测値と } \\
\text { の比較模定 }\end{array}$ & $(-)$ & $(-)$ \\
\hline
\end{tabular}

mm. Sliding Caliper を用い各々 3 回づつ計測しその平 均値を求め計測値とした。

なお，同一症例における生体直接計測の結果および生 体直接計測値と顎顔面模型による計測値との間における 差異を調べるために検定をした結果は表 2 のとおりであ る.

以上の結果, この顎顔面模型および計測法による䛊差 は僅少であり，測定值に影響を与えるものではなく，さ らに生体計測法による計測値との間に差異を認めず，こ の計測法および顎顔面模型はこの種の顎発育研究方法の 一つとして有効であることを認めた。

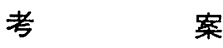

顎顔面の形態学的分析を行なら方法として従来より頭 部X線規格写真法, 規格写真法, 生体計測法, 模型計測 法等の方法が用いられている。これらの研究方法は各々 特徴ある性格を有しているが，いつれの方法においても 生体を立体的に把握し安定性の高い計測基盤を求めるこ とが望ましい。

頭部X線規格写真法は 1931 年 Broadbent ${ }^{15)}$ が主とし て矯正学的分野に応用して以来顎顔面頭蓋をあわせた形 態分析の方法として広く利用されて来た。ことに顎発育 研究分野においては Ortiz and Brodie ${ }^{16)}$ らにより乳幼 児に対する撮影装置の考案がなされ Pruzansky'12),17), Subtelny ${ }^{18)}$ らにより口唇口蓋裂患者の乳幼児期におけ る系統的研究が報告されている.しかしながら頭部X線 規格写真上の分析ではあくまでも立体である生体を一平 面に投影したものであり左右の計測点が区別し難い。し たがってロ唇・蓋裂患者の上顎骨のように左右に著明 
な相異を認めるような場合の計測には不向きであるとと もに水平方向の撮影が困難であるところに欠点をもって いる. 次に生体を直接的に計測する生体計測法は人類学 的分析方法として最も望ましい方法であるが，口腔内に 計測点を求め直接的に計測することは困難といえる．口 唇・口蓋裂患者の罘形態の分析によく用いられてきた模 型計測法は㴿形態を間接的に再現したものであり立体的 に印象づけるのに効果的である。ことに Simon ${ }^{19)}$ の澦 態模型あるいは著者の一人, 辻 ${ }^{14)}$ の考案した模型分析法 は計測基盤を顔面頭蓋にもとめ, これと口腔諸形態との 関係においてより安定な計測結果を得ることが出来た。

しかし Simon の顎態模型では口唇・蓋裂患者の形態 異常の主徵である鼻部, 上口唇部の印象がなく, これら の部位と上顎形態との関連性を追求するには顔面部印象 を必要とする.さらに乳幼児においては顎態模型調製器 のように多くの指示桿にて計測点を指示するには危険性 があるとともに Or. 点の指示に正確を期し難く水平基 準面の安定性を求める上で考虑を必要とした。著者等は 口唇口蓋裂患者における形態異常が主として上䫇および 上口唇, 鼻部に打いて著るしい(14)ことから上䕘歯槽部の 分析のみならずこれと密接な関係にある上口唇, 鼻部の 形態異常もあわせて追求する必要を認めた。このため罘 顔面部の併合印象とその模型に対し顔面頭蓋に計測基盤 を与えて立体的に観察すべき記録，計測方法を考案した。 水平基準面には計測人類学的立場 ${ }^{20)}$ から多くの平面が 記載されている. 耳珠点は著者の一人, 辻年) む検定した ように口唇・蓋裂による影響がなく指示容易な点であ るので採用したが，Or. 点は乳幼児の顔面部印象面上で 指示することが困難であり，さらに，これょり頭蓋に近 い点がこの種の計測には適している。このため著者らは 顔面印象面に印記出来るとともに生体計測上用いられる 内眼角点 (Entkanthion) を採用した。左右耳珠点およ び左右内眼角点の中点の三点によって構成されるこの水 平基準面は頭蓋計測学上理想的といわれるジラール前庭 水平面とフランクフルト水平面 ${ }^{20)}$ との中間に位置し, こ の種の計測および観察のための基準面として与えるのに 妥当であると考える.

\section{結}

\section{語}

口唇・口蓋裂患者の顔貌異常の治療を施行するために はこの種の患者の乳幼児期から成人に至る顎発育様相を 系統的に精査する必要がある.このためには顎顔面の状 態を頭蓋を基準として把握する必要がある．このために 従来の靧態模型の長所を受け入れた新らしい顎顔面模型 を考案した。これは, 口腔内上顎部と顔面頭蓋を $1 つ の$ 模型として再現したものである.この模型の製作方法, 計測方法と模型計測誤差について記載し口唇・蓋裂患 者の顎顔面発育成長研究の一方法として有効であること を認めた。

\section{文献}

1) Cooper, H., From Graber, T. M. : A study of craniofacial growth and development in the cleft palate child from birth to six years of age. International Symposium Edited Hotz, R. p. 30, Hans Huber, Publishers, Bern and Stuttgart, 1964.

2) Coupe, T.B., \& Subtelny, J. D. : Cleft palate-deficiency or displacement of tissue. Plastic Reconst Surg $26:$ 600-612 1960.

3) Peyton, W.T. : The dimensions and growth of the Palate in the normal infant and in the infant with gross mal-development of the upper lip and palate. Arch Surg 22 : 704-737 1931.

4) Peyton, W.T. : Dimensions and growth of the palate in infants with gross mal-development of the upper lip and palate. Am J Dis Child 47 : 1265-1268 1934.

5) Pruzansky, S. : Factors determining arch form in clefts of the lip and palate. Am J Orthodontics 41 : 827-851 1955.

6) Subtelny, J.D. : The significance of early orthodontia in cleft palate habilitative planning. J Speech and Hearing Disorders 20 : 135-147 1955.

7) McNeil, C. K. Congenital oral deformities. Brit Dent J $101: 1956$.

8) Nordin, K., und Johanson, B. : Frei knochentransplantation bei Defekten im Alveolarkamm nach kieferorthopadischer Einstellung der Maxilla bei Lippenkiefer-Gaumen spalten. Forschnitt d kiefer "Ges chir $1: 1681955$.

9）藤野 博, 他：口唇顎口蓋裂乳児に対する自家骨移植例 について. 口科誌 15:165 1966.

10）平川正辉：唇顎口蓋裂形成手術にあたっての骨裂隚補埧 に関する研究. 九州歯科学会雑誌 $19: 1965$.

11）佐々木元㹂：口展顎口蓋裂における Presurgical Dental Orthopedics. 口科誌 14:252 1965.

12) Pruzansky, S. : Factors Determining Arch Form in Clefts of the Lip and Palate. Am J Orthodont 41 : 8271955.

13) Hagerty, R. F. : Dental Arch Collaps of Cleft Palate. The Angle Orthodont 34:25 1964.

14）辻 忠良：口唇口蓋裂患者の上顎骨および上買歯列弓の 発育に関する研究. 口科誌 $15: 467-4881966$.

15) Broadbent, B.H. : A new $X$-ray technique and its application to orthodontia. The Angle Orthodont $1: 451931$.

16) Ortiz, M.H., \& Brodie, A. G. : On the Growth of the Human Head from Birth to the Third Month of Life. Anat Rec 103 : 311-334 1949.

17) Pruzansky, S. : Description, Classification, And Analysis of Unoperated Clefts of The Lip And Palate. Am J Orthodont 39 : 590-611 1953.

18) Subtelny, J. D., \& Rochester, N.Y. : Width of the naso-pharynx and related anatomic structures in normal and unoperated cleft palate children. Am J Orthodont $41: 889,1955$.

19) Simon, P.W.: On the necessity of gnathostatic diagnosis in orthodontic practice. Int J Orthodont \& Oral Surg 12: 11021931.

20）山崎 清: 顔の人類学. 天佑書房. 東京, 1943, p. 14-20. 